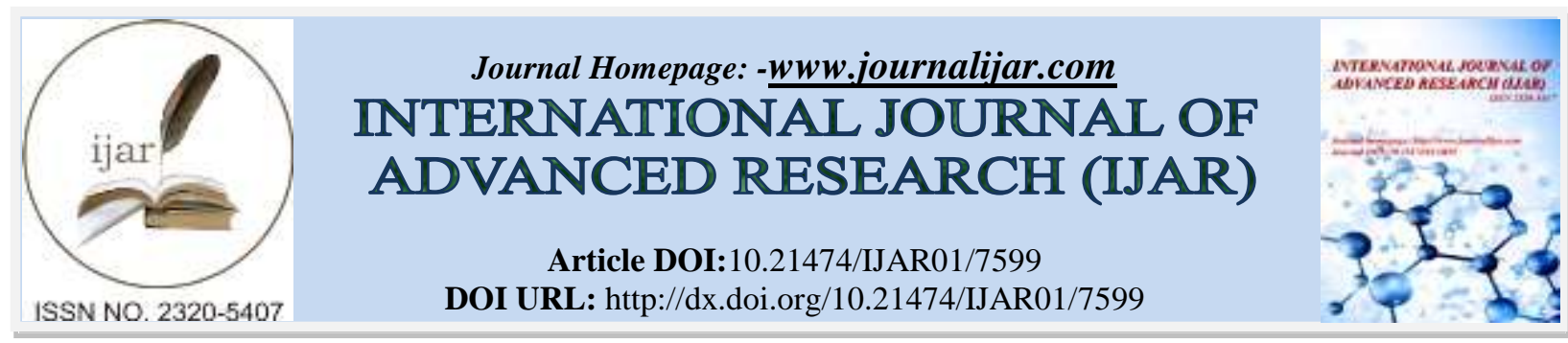

RESEARCH ARTICLE

\title{
CONTROL OF REGISTRATION ON LAND BOOKS IN MOROCCAN LAW.
}

\section{Dr. NADIR Bouchra, EL HALLIOUI Mouhssine and FSJES Souissi Rabat.}

1. Director of the Environment and Sustainable Development Laboratory.

2. Student researcher in the environmental law and sustainable development laboratory.

\section{Manuscript Info}

Manuscript History

Received: 20 June 2018

Final Accepted: 22 July 2018

Published: August 2018
Abstract

\section{Introduction:-}

Numerous are the regulatory texts of the registration system which provide for the supervisor's duty of control whenever he is faced with a right to register ${ }^{1}$, notably articles $72,74,94$ and $96^{2}$ of the Dahir of 12 August 1913 on land registration as amended and supplemented by Law $14-07^{3}$ as well as Article 4 of the Vizierial Decree of 4 June 1915 regulating the service of land conservation as it has been repealed partially by the decree of 14/07/2014 relating to the formalities of the land registration ${ }^{4}$.

The responsibility of the curator derives from his very function as much as the law. It is a consequence of the exercise of his profession ${ }^{5}$.

Thus, the powers of the conservator of landed property as an administrative authority, are manifested in the protection of law and public order. As a result, the registrar must comply with the applications for registration and the formality of registration on the land titles of the immovables under the registration system.

${ }^{1} \mathrm{Cf}$. MABROUK MAHLAOUI Amina, "Introduction to Moroccan land, legal approach", Ed. Ministry of Culture, 2015, p.30.

${ }^{2}$ Article 72 provides: "The custodian of the property shall verify, under his responsibility, the identity and capacity of the landlord, as well as the regularity, both in form and substance, of the documents produced in support of the requisition ". Article 74 provides that "The guardian of landed property shall be bound to ensure that the registration, which is the subject of the requisition, is not in contradiction with the declarations of the land title and the provisions of this law and that the pieces produced authorize the inscription ". Article 94 provides that: "The custodian of the landed property is obliged to ensure that the cancellation, object of the requisition, is not in opposition to the statements of the land title and the provisions of this law and that the documents produced authorize the radiation ". Article 96 states that:"In all cases where the custodian of the landed property refuses the registration or cancellation of a real right, his decision must be motivated and notified to the interested party. This decision is subject to appeal to the court of first instance, which rules on appeal. Judgments delivered are subject to appeal in cassation ".

${ }^{3}$ Official Bulletin $\mathrm{N}^{\circ} 6004$ of 19 moharrem 1433 (December 15, 2011), p. 2519.

${ }^{4}$ O.B. 6277 of $28 / 07 / 2014$.

${ }^{5}$ ZINE-DINE Aissam, "The Reform Provided by Law 14-07 Faced with the Malfunctions of the Regime of Land Registration", IMP. Najah Al Jadida, 1st Ed., 2014, p.123. 
As well as that the registrar is in charge of the particulars to be given to the land books concerning the real rights and land charges constituted on the registered buildings and all the formalities subsequent to the registration ${ }^{6}$. Its powers cannot be exercised far from the land regulations as well as the other legal texts including the Dahir obligations and contracts, as an additional law that the conservative can resort to when there is a legislative gap to level of special provisions governing land law.

To better understand the role of the registrar in the control of the validity of the acts, we will try to highlight some problems concerning the intervention of the curator during the verification of the regularities of application of the rules governing the obligations and the contracts, through its competence to reject the registration of the acts either because of absolute nullity or for rescission (First part). Therefore, the control exercised by the curator is paramount and must be meticulous in order to protect the validity of the contracts and the regularity of the inscriptions mentioned on the land titles (Part Two).

\section{Part I:-The Control Of The General Rules Of Obligations By The Conservative Of The Tenure Property} Contractual obligations validly formed stand in the place of law to those who have made them ${ }^{7}$. The role of the conservator of the land property in this respect is to assess ex officio the nullity of the acts, in order to ensure the validity of the contracts, as the authority of protection of the land books submitted to its custody.

\section{Paragraph 1:-The conservator and the devotion of the will of the contractors}

Acts writable on the land books are subject to the rules and legal provisions organizing the obligations in a general way. These provisions vary according to the cases of law that are filed with the curator. The role of the latter is to translate the will of the contracting parties by its inscription on land titles. In parallel with the registration of the principal rights such as the sale, the curator may enter conditions of resolution, restrictions of the right of disposal or special mention the registration of which is required at the same time as that of the principal right ${ }^{8}$.

This requirement is not new, the former Article 69 of the Dahir of 1913 refers only to the secondary conditions of the main act which should be writable on the land books, without any indication of the formalism of inscription ${ }^{9}$.

However, the Moroccan legislator has submitted the transfer of real property rights to special procedures aimed at protecting contracting parties and third parties who are opposable to the obligation. This was stated in Article 67 of Law 14-07, which provides that "Voluntary acts and contractual agreements to constitute, transmit to third parties, recognize, modify or extinguish a real right shall not be effective, even between the parties, from the registration on the land title ", this act when it has been approved by the curator and deemed to be registered on the land title has become legal proof exists with respect to third parties, and that the indications mentioned on title to the registered right can not be the subject of a claim or claim other than those registered on the land title. This means that rights in land titles are probative and have a constitutive effect on parties and third parties ${ }^{10}$.

According to the rules of the contract of sale emanating from the provisions of the DOC which stipulate that: " the sale is perfect between the parties, as soon as there is consent of the contractors, one to sell, the other to buy, and that they agree on the thing, the price and the other clauses of the contract"11. On the other hand, even this provision of validity, the sales contract has no legal effect as soon as it has been registered on the land title object of the sale.

The obligation to transfer the right of ownership is the main basis for giving legal effect to the various acts, and their registration on the land title triggers the starting point of the other obligations related to the registered right either

\footnotetext{
${ }^{6}$ Direction de la conservation fonciere, the land registration in 300 questions-answers, 2001, p.165-166.

${ }^{7}$ Article 230 provides that: "Contractual obligations validly formed shall be the law of those who made them, and may be revoked only by mutual consent or in the cases provided for by law".

${ }^{8}$ V. Article 69 of Law 14-07 amending and supplementing the Dahir of 9 Ramadan 1331 (12 August 1913) on land registration.

${ }^{9}$ The administrative practice in most of the external services of the land conservations has derived that the request in accordance with Article 69 is completed by the agents in charge of receiving the cases, "V. Practical Handbook of Land Retention".

${ }^{10}$ IRBOULI Said, "Land registration and protection of the rights of third parties", memorandum of DES in private law, CASABLANCA, 1987.

${ }^{11} \mathrm{~V}$. Article 488 of the DOC.
} 
with respect to the parties or against the thirds. Therefore, the buyer must do what is necessary to register his right to be valid, and in case of refusal from the seller, he must resort to justice to try an action for require the buyer to proceed with registration. Indeed, the court of cassation by many judgments has forced the seller to resort to conclude the procedure of the sale by its registration on the land title on the basis of the obligation of guarantee emanating from the seller ${ }^{12}$.

However, the obligations have an effect, not only between the parties themselves, but also between their heirs or successors in accordance with Articles 229 and 230 of the DOC. In fact, in the event that the custodian of the property receives a contract of sale initially prior to the death of the seller, while the heirs of the latter have entered the deed of succession on the land titles, in which case the conservator can not apply the rules of civil law and consequently does not have the right to automatically cancel the act of inheritance by virtue of the provisions of articles 229 and 230 and to replace the previous sale of the death ${ }^{13}$. The registrar may not strike off the registration unless the cancellation is based on article 91 of Law 14-07 which provides that "the inscriptions, mentions and prenotations made on the land title may be struck out under any act or any judgment passed into res judicata ".

\section{Paragraph 2:-the competence of the registrar in the nullity of the obligations}

Absolute nullity is when the act of invalidity reaches a general interest which can be pronounced ex officio by the judge. The obligation is null by operation of law, it is when it misses one of the substantial conditions of its formation or when the law enacts the nullity in a certain case. However, the rescission exists when the error falls on the species, or the quality of the object that was the determining cause of the consent. Thus, this is correctable and can give if the parties wish to the continuity of the contract ${ }^{14}$.

As a result, the curator by his role consecrating the principles of contracting and maintaining legal and contractual security, on the basis of his responsibility emanating from the law, under the control of contracts and the regularity of acts, both in the form that basically absolute nullity is when the act of invalidity reaches a general interest which can be pronounced ex officio by the judge. The obligation is null by operation of law, it is when it misses one of the substantial conditions of its formation or when the law enacts the nullity in a certain case. However, the rescission exists when the error falls on the species, or the quality of the object that was the determining cause of the consent. Thus, this is correctable and can give if the parties wish to the continuity of the contract.

As a result, the curator by his role consecrating the principles of contracting and maintaining legal and contractual security, on the basis of his responsibility emanating from the law, under the control of contracts and the regularity of acts, both in the form that basically writable on land titles ${ }^{15}$. Therefore, the curator is bound to automatically raise the absolute nullity, in order to consecrate the general order, and on the other hand, the contracting party, who has a personal interest can seize the rescission of the act before the competent jurisdiction.

It should be noted that the raising of the nullity by the conservative, finds its base in the provisions of article 306 of the DOC, which aims to verify the conformity of the substance of the act object of the inscription, and to classify it in a valid writable act on the land books or refuse it by a reasoned and justified decision which must be notified to

12 V. Judgment of the Court of Cassation No. 7-8 dated 08/01/2013 file no. 3455-1-1-2011.

13 The Court of Cassation in its judgment $n{ }^{\circ} 4257$ of October 4, 2011, civil file $n^{\circ} 3793 / 1 / 1 / 2009$ concluded that: "in the system of publicity of the registered buildings, the conservator must proceed, under its responsibility, verification of all applications for registration addressed to it. He can give official recognition of his records only rights existing on the building, in accordance with the provisions of Article 74 of the Organic Dahir on registration, it is therefore right the decision of the Registrar to refuse registration of a succession of the one who is no longer owner since the statements of the land title are in opposition to the inscription object of the requisition. See "Review of Land Records", Publications of the Court of Cassation No. 2 of 2012, p.119.

14 Omar AZZIMAN, the civil law, Ed. Le Fennic, 1995, p. 291.

15 Not only according to the provisions of the land law but also on the point of law in general. Therefore, when the lawyer PAUL DECROUX enacts that the control of registrations by the curator is a purely formal control, he misjudged this provision because the curator is responsible before the law in case of irregularity of registrations, that's why must verify the acts both in form and in substance. The conservator of the land property in Morocco is not like his counterpart in France that he is just holds and keeps the contracts then and he transfers them on behalf of the owners without any control. 
the interested party ${ }^{16}$. In fact, the registrar refuses the registration of the acts affected by the nullity on the basis of the provisions of the second paragraph of article 306 of the DOC, by general considerations, such as not obtaining a prior authorization to conclude a contract required by law, or to obtain a prior authorization of parcelling required by article 58 of the 25-90 which expressly stipulates in its article 61 that "the conservators of the property must refuse to register all acts relating to the sale or partition transactions referred to in Article 58 without the authorization provided for in that Article or an attestation from the chairman of the communal council certifying that the transaction does not fall within the scope of the law 25-90" under penalty of the nullity of the act. As the case law has confirmed by many judgments that the acts concluded in the absence of the authorization stipulated by article 58 , will be null and produce no effect ${ }^{17}$.

On the other hand, the law required in certain cases the nullity of the contracts when they are drawn up during a definite period. Land ownership subject to these restrictions that limit the use of property rights, are often related to the legal particularity of land ownership. For example, the law governing the administrative delimitation procedure the private domain of the State or the ethnic lands ${ }^{18}$, requires a period of prohibition where any voluntary act established during this period is struck by the absolute nullity, and that the conservator of the landed property can lift it during his registration.

In parallel, and for reasons of the peculiarity of the exchange of land ownership between peasant landowners during the rural land consolidation procedure, the legislator has required a blackout period in which any voluntary act tending to transfer the property is null and void. producing no legal effect under the provisions of Article 4 bis of 30 June 1962 as amended and supplemented ${ }^{19}$, and therefore the Registrar must refuse the registration and automatically raise the invalidity of the act.

Article 311 of the DOC provides that the action for rescission takes place in the event of a contract entered into by a minor or an incapable person without the authorization of his / her legal guardian or guardian or his / her guardian, as well as when consented in error, surprised by fraud, or extorted by violence, or where one of the injured party is a minor or incapable, even in cases determined by law such as the cancellation, modification or cancellation of the entries in a fraud, forgery and use of fake.

The custodian of the property may refuse to register or deposit any deed, when it finds that it is affected by a defect of consent, such as the incapacity of one of the parties to the contract without asking for authorization the juvenile judge. The Conservative intervenes according to the rules of law and is considered as a protector of law and then a guardian of the will of the parties against any fraudulent maneuver ${ }^{20}$.

On the other hand, when the curator is unable to trigger the nullity of the acts, the action of nullity of the act registered on the land title can be raised by any person having interest before the justice. For example, in the case of a simulation of acts, which can take many forms, such as a misrepresentation of the actual price of the sale, in order to reduce tax rights, or to deprive one of the co-owners of exercising their right to preemption that

It is conferred by law, by concealing the deed of sale by a donation, such cases the registrar inscribes these acts even if they are burdened with simulation, because he is unable to cause the annuality of these latter. Therefore, any person having an interest in trying an action in court for the nullity of the act burdened with simulation, thereafter

16 Article 96 of the $14-07$

17 Judgment of the Court of Cassation No. 662 of 27 September 1978, civil file No. 51984, In. "Legal Yearbook of Land Registration", publication of the Directorate of Land Tenure, first issue, 2002, p. See also Judgment of the Court of Cassation No. 8-599 dated 21/11/2017 file no. 6747-1-8-2016. (non published)

${ }^{18}$ Dahir of January 3, 1916 laying down special regulations on the delimitation of the domain of the State, OO, No. 168 of January 10, 1916, p. 36. See also the Dahir of February 18, 1924, on the special regulations for the delimitation of collective lands, B.O., of March 25, 1924, p.542.

${ }^{19}$ Article 4 bis (Added, D. No 1-69-32, 25 July 1969 - 10 joumada I 1389, Article 2) provides that: "From the date of publication in the Official Bulletin of the notice announcing the deposit at the headquarters of the local authority of the state and plan parcellaires and until the decree homologating the project of consolidation, are prohibited under penalty of nullity all voluntary acts, free of charge or against payment, having for object the total or partial transfer, exchange or division of land included in the consolidation area concerned by this publication. "Soundtrack of 20/07/1962.

${ }^{20}$ Article 2 of the Real Law Code to limit the limitation period in four years to bring an action before the court 
the registrar may strike it off on the basis of a judgment having the force of res judicata according to the provisions Article 91 of Law $14-07^{21}$.

Law 39-08 on real rights stipulates in article 19 that: "Real estate is the right to use, enjoy and dispose of a building in the most absolute way, and it restricts only by the law or by agreement ". Thus, if the act meets the conditions of validity (substantive and form), but has a condition of perpetual ban of alieniers, the curator finds himself in two situations, or he refuses to register the act for cause prohibition attached to it because it is considered one of the attributes of the right of ownership, and which is completed only with the union of the three attributes. Or it inscribes it in its state by respecting the provisions of article 230 of the DOC and article 14 of the code of the real rights which stipulates that the right of ownership can be limited by the agreement of the parts.

The provocation of the absolute nullity of the acts and conventions by the conservator of the property property emanates from its responsibility which consists in the meticulous control of the regularity of the acts objects of inscription on the land books. As a result, the provisions of Article 110 of the DOC which expressly state that the condition inconsistent with the nature of the act, (property right case) to which it is added is null, renders the obligation dependent upon it. nothing. Therefore, if the registrar refuses to register an act that carries a lifelong blackout condition that is considered valid, his decision will be based on a legal basis that justifies his refusal ${ }^{22}$.

\section{Partie Ii:-Le Contrôle De La Validite Du Fond Et La Regularite Formelle Des Actes}

Voluntary acts and contractual agreements tending to constitute, transmit to third parties, recognize, modify or extinguish a real right do not produce effect, even between parties, only from their inscriptions on the land title. This registration can be obtained only by a control of the regularity of these acts by the curator, as well in the form as the exigibility of the authentication of the acts, that in the bottom like the capacity of the contractors.

\section{Paragraph 1:-control of contractual capacity}

The custodian of the property is personally liable for the damage resulting from his omission in his records of an inscription, mention, prenotation or cancellation in accordance with the provisions of Article 97 of Law 14-07. Knowing that the first challenge faced by the curator during his mission of control of the acts is the verification of the capacity of the transferor and the assignee, and this in order to concretize the principle of legality of the inscriptions and its convincing strengths.

Capacity control under Law 14-07 is classified into two phases, either when establishing title deeds following registration or when registering real rights in land titles. Article 55 of Law 14-07 provides that where the land title is established, or a real right is entered in the name of a minor or an incapable person, the age of the minor or the nature of the incapacity are indicated on the land title, without linking this provision to any liability against the curator. Although in the context of the publication of real rights over land titles, the legislature has assumed a great personal responsibility to the custodian of landed property for damages resulting from any omission or irregularity in his records of an inscription or mention. Also, the legislator obliged the curator according to the provisions of article 72 of 14-07 to verify, under his responsibility, the identity and the capacity of the landlord. The reason for this difference in the burden of liability is that the land registration procedure consists of several steps and a wide publicity, so the applicant's capacity would be verified by the fact of advertising, on the other hand the formalism of the inscriptions is done in a wayfast without insertion, and for which the legislator has assumed a responsibility to the curator during the registration procedure.

Registration is the essential condition for the exercise of the right and between the parties themselves, and with regard to third parties. Therefore, the custodian of the property is required to verify, under his responsibility, the identity of the landlord and the capacity to alienate and bind himself.

${ }^{21}$ Article 91 "Subject to the provisions of Article 86, the inscriptions, mentions and prenotations made on the land title may be canceled by virtue of any act or judgment having the force of res judicata finding, in the eyes of the persons concerned, the the existence or extinction of the right to which they relate".

22 M'RABET Abdeillah, "the vision of the green conservative code of obligations and contracts", Centenary of the Code of Obligations and Contracts (1913-2013), Volume 1: the preparatory work organized on 27/01 / 2012-15 / / 03 / 2012-11 / 05/2012, publisher private law laboratory Faculty of Economic and Social Legal Sciences of Agdal Rabat, 1st edition 2012. 
Legal guardianship, testamentary guardianship or dative tutelage are legal institutions to manage the property of minors and the incapable for its interests, under the control of this legal representation by justice ${ }^{23}$.

However, the dissipation of different provisions dealing with legal representation can put the conservator in a lost position, at the moment an act is presented to the conservative that requires authorization from a juvenile judge. Section 11 of the RFSO provides that the legal guardian who administers the property of a minor or incapable child, the tutor, the curator, may not make any disposition of the property under their management until after having obtained a special authorization of the competent magistrate, in other words Article 1119 of the DOC provides that the minor can not surety, even with the authorization of his father or guardian, if he has no interest in the case that he guarantees. On the other hand, Articles 152 and 178 of the Real Rights Code provide that the legal guardian or guardian or curator can not mortgage or make an anti-mortal on the property of minors or incapacitated persons until he has obtained a judge's authorization. As a result, the provisions of the DOC and the Code of Rights in rem do not differentiate between acts emanating from the legal guardian, the testamentary guardian and the curator, except that its provisions always require the authorization of the juvenile judge. While, the provisions of the law 70-03 bearing family code ${ }^{24}$ distinguished between the acts emanating from the legal guardian on the one hand and the acts of the guardian and the curator on the other hand. Articles 240 and 241 of the Family Code required the legal guardian, when managing the property of the prohibited, only to open a file of legal representation to the General Ministry without it being necessary to obtain the prior authorization of the judge in charge of guardianship, contrary to the case of the testamentary or dative guardian, that the provisions of Article 271 of the Family Code, require the authorization of the judge in charge of guardianship if they have made a sale of a property of the prohibition whose value exceeds ten thousand dirhams $(10,000 \mathrm{DH})$ or create a real right on this property. Consequently, the acts of the legal guardian are exempted from a judge's authorization, against those of the testamentary or dative tutor, in accordance with the provisions of the family code.

To unify the work between the Conservatives and to overcome the differences between them, the Conservative General drew up a memo $n^{\circ} 1314$ dated 16/06/2014 concerning the acts performed by the guardian concerning the property of his minor son, according to which the acts of the legal guardian are exempted from providing authorizations of judge in charge of guardianship, provided to take into consideration the provisions of article 269 of the family code ${ }^{25}$ relating to the contradictions of interests.

At the time of the promulgation of the code of the real rights, it was envisaged the need to approach the problem of the authorizations to the acts carried out by the legal representatives, in particular during the registration of the small acts by the tutelage on the land titles. Notwithstanding that articles 152 and 178 of the code of the real rights require the authorization of judge when the legal representative carried out a mortgage or an anti-mortar on the property of the minors or the incapables. But what about other acts relating to real estate such as the sale for example, does it require a judge's authorization such as that of the mortgage or the anti-mortar or the latter have a more dangerous effect? in relation to the deeds of ownership, knowing that the mortgage can turn into a forced sale in the event of insolvency?

A problem must be raised concerning the mandate or the conventional representation, in particular article 894 of the DOC. The mandate is a contract by which a principal gives power to a principal who undertakes to perform a lawful $\mathrm{act}^{26}$. Therefore the attorney must present a power of attorney valid in substance and in form, under which the act must be concluded ${ }^{27}$. Article 894 of the DOC provides that the agent may not alienate immovable property or immovable property, constitute a mortgage or pledge, cancel a mortgage or waive a guarantee, without the express

${ }^{23}$ Omar AZZIMAN, Civil Law, Op.Cit., p. 112.

${ }^{24}$ B.O No. 5358 of 6 October 2005 , p. 667.

${ }^{25}$ Article 269 provides that: "If the legal representative intends to undertake an act which opposes his interests, those of his spouse or those of one of his ascendants or descendants, to the interests of the interdict, he seizes the court, which may authorize it for this purpose and designate a representative of the prohibition for the conclusion of the act and the preservation of the interests of the prohibition ".

${ }^{26} \mathrm{~V}$. Article 879 of the DOC

${ }^{27}$ V. Judgment of the Court of Cassation No. 1875 of 09/06/2004, Civil File No. 502/1999 "declares that the bill of sale with a falsified power of attorney is deemed null and void", In "Provisions of land registration in the light of the judgments of the Court of Cassation", publications of the Court of Cassation, 2009. 
authorization of the principal, the aforementioned article does not the nature of the mandate, whether special or general. That's why the actmade on an immovable by virtue of a power of attorney requires that the contract of mandate contains all the data on the immovable subject to the warrant, specifying the type of the transaction made by the agent as well as the clause to take and deliver the price. That is why the Conservative General clarified the provisions of Article 894 of the RFSO by his letter No. 823 dated February 12, 2007, which confirmed that the power of attorney stipulated by Article 894 is the special power of attorney which must contain all the indications as well as the land reference of the property object of the mandate.

The second issue facing the Conservatives is the removal of the mandatary, which does not take effect until the agent has received the communication terminating his mandate and in accordance with the provisions of article 932 from the DOC. In fact, the revocation of the attorney produces no effect with respect to registrations on the land books only by the receipt by the curator of a letter by the principal justifying the notification of the attorney of his revocation by way of official notification ${ }^{28}$.

\section{Paragraph 2:-control of contractual formalization}

Article 489 of the DOC provides that: "Where the sale relates to immovable property, real estate rights or other things liable to mortgages, it must be made in writing having a definite date". However, the problem of the formalization of the contracts carried out on the real property or real rights immovable property, was settled by the promulgation of the code of the real rights in 2011 in particular the article $4^{29}$ which stipulates that the acts relative to the transfer of property or of create, transfer, modify or cancel rights in rem as well as the mandates relating thereto, must be drawn up, under pain of nullity, in the authentic form or under private seal established by a lawyer approved at the court of cassation. Consequently, Article 4 of the Real Rights Code comes to establish the legal form of the acts that may be registered in the land titles, as well as to facilitate the task of controlling the documents deposited with the registrar, in order to ensure the validity conventions and then provide contractual guarantees for any spoliation or false ${ }^{30}$.

In fact, when a contract does not comply with the provisions of Article 4 of the Code of the rights in rem would be considered null and without object, and this in accordance with the provisions of the article 306 of the DOC which stipulates that: "the obligation null and void and can not produce any effect, except the repetition of what has been unduly paid in fulfillment of this obligation, even the obligation is also null by operation of law: When it lacks one of the substantial conditions of its formation or when the law enacts the nullity in a particular case ".

On the other hand, the legislator of the code of the real rights demands for the establishment of a contract of special character in the authentic form, at the same time under penalty of nullity or considered as a condition of its validity. Its contracts are fixed as follows: OUMRA contract, antichresis, ALMOGHARASSA, donation. However, if a contract of donation chaplain of an apartment subjected to the regime of the co-ownership was drawn up by an act having a definite date established by a recognized lawyer with the court of cassation, in accordance with article 4 of the code of the rights as amended and supplemented and Article 12 of Law No. 18-00 on the status of co-ownership of immovable property as amended and supplemented by Dahir $\mathrm{N}^{\circ} 1-16-49$ of April 27, 2016 promulgating the law $\mathrm{n}^{\circ} 106-12$, although this contract has met all the conditions of its validity, the conservator of the landed property can refuse his inscription in the land books on the basis that the article 274 of the Code of Real Rights requires the authentic form of acts of donation under pain of nullity. The problem was brought before the court, resolved by the judgment of the court of cassation which held that "Article 4 of the code of the rights real is a general text which includes all the acts which they have for object the transfer, modification or cancellation of a right of ownership or a real right, subject to the limitation of its generality by article 274 of the Code of the real rights which requires the authentication of the donation under penalty of nullity, and that the Authentic deed must be established by a public officer in accordance with the provisions of Article 418 of the RFSO. On the other hand, the act drawn up by a lawyer accredited before the court of cassation is free from all the characteristics of the authentic instrument and thus considered as a private deed according to the provisions of article 4 of the code of the real rights "Same thing for acts done by a business manager. In the absence of the joint order of the Minister of Justice, the Minister of

\footnotetext{
${ }^{28}$ V. Circular of the Registrar General No. 858 dated 09/04/1993.

${ }^{29}$ The law $\mathrm{n}^{\circ} 39-08$ relative to the code of the real rights promulgated by the dahir $\mathrm{n}^{\circ} 1.11 .178$ of the 22 November 2011 such as the article 4 was modified and supplemented by the law 69-16 promulgated by the dahir $\mathrm{n}^{\circ} 1.17 .50$ of August 30, 2017. .BO No. 6604 dated December 14, 2017. (Arabic version)

${ }^{30}$ See the Royal Letter of 30/12/2016 addressed to the Minister of Justice and Freedoms concerning land plundering.
} 
Agriculture and Rural Development and the Minister Delegate to the Prime Minister in charge of housing and urban planning, which lists the other legal and regulated professions authorized to draw up the acts referred to in Article 12 of Law 18-00 as amended and supplemented by Law no. ${ }^{\circ} 106-12$, as well as its Decree taken for the application of article 12 of the law ${ }^{\circ} 18-00$ relative to the status of the co-ownership of the buildings built ${ }^{31}$.

In fact, the control of authentic deeds notarized by the curator, according to the principle of article 72 of the law 14 07 , with the conformity with the provisions of article 49 of the law $n^{\circ} 32-09$ relative to the organization of the profession of notary, promulgated ${ }^{32}$, which provides that any act received in the authentic form and drawn up in violation of the provisions of articles $30,31,32,37,39$ and 40 of this law (32-09) is null ». This control by the curator on the notarial deeds is considered as a collaboration and continuation of the drafting of the act in order to enter it on the land register in due form, in order to guarantee the regularity of the real estate agreements and also to ensure the responsibility of both the notary and the curator. As a result, Law 32-09 eased the burden of the curator's responsibility to control notarial deeds, which in his article 37 states that "The notary shall, under his responsibility, ensure the identity and quality of the parties, their ability to dispose and compliance with the law documents produced ", parallel to the personal responsibility of the curator resulting from the irregularity and nullity of registrations, mentions, prenotations or write-offs on the land title.

\section{Conclusion:-}

The custodian of land ownership is a legal institution whose original competence is to raise the rules of obligations and contracts in order to guarantee and protect contractual security on the one hand and to dedicate the principles of land governance on the other hand.

${ }^{31}$ Law No. 18-00 on the status of co-ownership of immovable property as amended and supplemented pursuant to Article 1 of Dahir No. 1-16-49 of 19 rejeb 1437 (April 27, 2016) promulgating Law No. 106-12 which provides that: "On pain of nullity, any act relating to the transfer of the co-ownership or the constitution, the transfer, the modification of a real right or the extinction of said right, must be established by a deed or by a deed at a certain date drawn up by a professional belonging to a legal and regulated profession authorized to draw up such acts by the law governing the said profession. The list of registered professionals to draw up these acts is fixed annually by the Minister of Justice. The registration conditions of the other approved professionals to draw up these acts are fixed by regulation. Official Bulletin No. 1664 of (November 3, 2016), p. 1664.

Decree $n^{\circ} 2-03-852$ of 18 rabii II 1425 (June 7th, 2004) taken for the application of article 12 of the law $n{ }^{\circ} 18-00$ relative to the status of the co-ownership of the built buildings, Official Bulletin $n^{\circ} 5222$ of 28 Rabii II 1425 (June 17, 2004), p. 904.

${ }^{32}$ O. B. $n^{\circ} .6062$ of July $5,2012$. 